\title{
Properties of Concrete Made from Cupola Furnace Slag and Recycled Construction Aggregates
}

\author{
A. J. Adese, O. D. Olajide, and O. A. Olaoyenikan
}

\begin{abstract}
The replacement of traditional constituents of concrete with waste has garnered a lot of interest due to the increasing demand for natural resources used in concrete production. Hence, this study presents the outcome of an experimental investigation on the effect of partial replacement of Ordinary Portland Cement (OPC) at percentage levels of $0 \%$ to $25 \%$ in steps of $5 \%$, partial and complete replacement of sand and granite in the percentage of 0 to 50 in steps of $10 \%$ with cupola slag and recycled construction aggregates. The fresh and hardened properties of concrete such as workability, compressive strength, and microstructural characteristics were assessed. The test results showed a decrease in workability as the percentage replacement of cupola furnace slag (CFS) and recycled construction aggregates (RCA) increases. Concrete produced at 28 days from the partial replacement of cement and sand with cupola slag has an optimum compressive strength of $20.37 \mathrm{~N} / \mathrm{mm}^{2}$ at $10 \%$ and $22.81 \mathrm{~N} / \mathrm{mm}^{2}$ at $20 \%$, resulting in improved strength of $29.4 \%$ and $56.82 \%$, respectively when compared with the control. In contrast, granite's partial replacement with coarse cupola slag and complete replacement of sand and granite gave a lesser compressive strength when compared with the control samples at $7,14,28$, and 56 days. The porosity of the concrete with optimum compressive strength from each mix was studied using microscopic and image analysis. The result showed that the addition of cupola slag in granulated and fine forms decreases the porosity, hence leading to higher compressive strength.
\end{abstract}

Keywords - Cupola furnace slag, Recycle construction aggregates, Compressive strength, Waste recycling, Porosity.

\section{INTRODUCTION}

Concrete is an undeniably versatile material for the construction and infrastructural development of any nation. However, the adverse environmental effects involved in its production are some of the downsides of its usage. This has prompted many researchers into looking at how waste materials can be recycled and used in concrete production while the strength and durability properties will still be achieved. The industrial growth witnessed in recent times has increased the amount and type of waste produced locally and internationally, consequently leading to the problems of waste management worldwide [1].

Conversely, waste can be a valuable resource if managed appropriately which in turn can eventually help conserve our natural resources, promoting sustainable development and reducing space required for landfills [2]. [3] discovered that solid waste management is a major problem in most developing countries. Research and innovative ideas are being taken up worldwide to ascertain the economic viability

Submitted on October 31, 2021

Published on November 22, 2021

A. J. Adese, Civil Engineer, Nigeria.

(e-mail: adeseakorede@ ${ }^{@ m a i l . c o m) ~}$ and feasibility of waste reuse in concrete production [4]. The materials used for cement production such as limestone is reported by [5] to be consumed in large quantity and it is predicted that some parts of the world may fall short of it soon. The reuse of industrial by-products and post-consumer wastes for cement production is becoming a thing of necessity, for the production of "greener" concrete capable of improving air quality, minimizing solid waste, and leading to sustainability in the built industry.

Several research has been carried out on the use of industrial wastes, by-products, and recycled materials for partial replacement of cement and aggregates in mortar and concrete. The compressive strength and rheological behavior of mortar from the partial replacement of cement with bottom biomass and fly ash was studied by [6]. It was concluded that at 5\% replacement of cement with ash in the concrete, a comparable value with the control mix was gotten. However, further replacement of cement with ash to $30 \%$ resulted in a progressive decrease in compressive strength. [7] also used forest waste bottom ash to partially replace cement in 5 and 10 percent. The compressive strength and the durability of the hardened concrete were studied, they noticed a decrease in strength as the ash content increased at 28 days. In addition, they observed a $12 \%$ increase in strength when compared with the control at 90 days. The durability and mechanical properties of concretes produced from the partial replacement of cement with ground granulated blast-furnace slag (GGBS) and crushed waste glass powder (GP) were studied by [8]. They replaced cement with GP from 5\% to $45 \%$ and GGBS from $45 \%$ to $5 \%$ in step of $5 \%$. At curing days of 3, 7, and 28 the compressive strength from each mix was obtained. A combined mix of cement + GP + GGBS was prepared using a mix ratio of 50:15:35 and 50:20:30. An increment of $44.2 \%$ and $43.08 \%$ respectively was observed when compared with the control mix. In addition, the split tensile strength increased by $9 \%$ for the former and $7.6 \%$ for the latter. Also, there was a reduction in the water absorption rate and the sorptivity rate. They finally concluded that GBBS and GP can be effectively used as cement replacement in the percentage of $35 \%$ and $15 \%$, respectively in concrete production. The curing methods suitable to achieve a good compressive strength of sustainable self-consolidating concrete were experimented by [9]. In their study, $90 \%$ of cement was replaced with recycled combinations of fly ash, silica fume, and ground granulated blast-furnace slag (GGBS) with water/binder ratios of 0.36 and 0.33 . Compressive strength test results showed that curing under

O. D. Olajide, Department of Building, Civil and Environmental Engineering, Concordia University, Montreal, Canada.

(e-mail: olusola.olajide@ concordia.ca)

O. A. Olaoyenikan, Civil Engineer, Nigeria.

(e-mail: Olajidealaba53@gmail.com) 
direct sun produced the highest strength after 28 days of curing compared to using a curing compound or using the traditional method where concrete samples are submerged in water. Furthermore, using an acrylic-based curing compound gave a higher strength development in relation to the traditional curing method of submerging concrete samples under water for 28 days.

Both fine and coarse aggregates can also be made of recycled materials like foundry sand, glass, ceramic wastes, construction and demolition (C\&D) waste, etc., however, national regulations and technical issues pose setbacks for its usage. [10] examined the possibility of using crushed clay bricks as coarse and fine aggregate for new concrete and they found out that with the percentage of recycled aggregates limited to $25 \%$ for coarse aggregate and $50 \%$ for fine aggregates, the concretes produced have similar characteristics to those of natural aggregates. [11] also concluded that conventional coarse aggregates can be replaced up to $40 \%$ with crushed ceramics without the design strength being affected. [12] completely replaced fine aggregates with rubber and discovered that the concrete produced reduced the sound insulation and thermal conductivity by 69 and 59\% respectively. They concluded that rubber can be used in concrete production as aggregates to improve sound insulation. [13] also concluded that replacing natural aggregates with rubber in concrete improves the noise reduction effect when compared with the control concrete without rubber. Some researchers like [14], [15], and [16], reported a decrease in compressive strength when recycled waste plastics are used as aggregates. However, [17] and [18] noticed a different trend. [17] observed an increase in compressive strength when the percentage of plastic used is below $20 \%$. They concluded that the source of the plastic used was responsible for the increase in strength. They made use of industrial plastic floorboards which might be stronger than the one used in similar research. [18] made use of PET plastics at $10 \%$ replacement level. They attributed the increase to the plastic being present at the position where the concrete begins to fail.

This study focused on the determination of strength and durability properties of concrete made with cupola slag; an industrial waste, obtained from pig or cast-iron production in a cupola furnace, and recycled C\&D aggregates (sandcrete hollow blocks and concrete cubes). While construction and demolition (C\&D) aggregates are unwanted nonhazardous materials generated during construction, they possess low mechanical and durability properties in relation to NAC [19]. The recycled aggregates are combined with fine and coarse cupola slag in this research to evaluate their performance through the production of concrete cubes in varying replacement and to validate and encourage recycling and reuse of industrial and construction waste.

\section{A. Materials}

\section{MethodOLOGY}

The materials used to accomplish the aim of the study include OPC, Cupola furnace slag (CFS), crushed recycled sandcrete blocks, crushed recycled concrete cubes, sand, and granite. The CFS was obtained from the St. Daniels foundry site in Akure, Nigeria, where it is dumped as a waste product.
Impurities were removed from the cupola slag and later taken to the lab where it was crushed to sizes between $5 \mathrm{~mm}$ to 20 $\mathrm{mm}$ for the coarse aggregate using a jaw crusher. A pulverizing machine was later used on the cupola to get fine aggregate lesser than $5 \mathrm{~mm}$ diameter and finally, it was ball milled to granulated form and passed through a $75 \mu \mathrm{m}$ sieve similar to cement particle size. Dangote 3X Ordinary Portland Lime Stone Cement (OPLC) of grade 42.5 according to the requirements of BS 12 (1996) which also served as an activator when partially replaced with recycled granulated cupola furnace slag was used. It was locally purchased in Nigeria in $50 \mathrm{~kg}$ bags. Natural sand and granite used were locally sourced in Akure, Ondo State, Nigeria. The sand and granite used were free from deleterious materials and met the requirements of BS 882 (1982). The water used was generally pure and fit for drinking purposes which also met the requirement in BS 3148 (1980). Crushed sandcrete block served as the recycled fine aggregate (RFA) while crushed concrete cubes were used as recycled coarse aggregate (RCA). Both were obtained from the structural laboratory of the Federal University of Technology, Akure. They were crushed manually with the use of a sledgehammer to achieve smaller particles and later sieved in the geotechnical laboratory to obtain the recommended particle size given in BS 882 (1985).

\section{B. Concrete Mix Design}

Five different mixes were designed to investigate the performance of concrete made from binary cement (OPC and granulated cupola furnace slag (GCFS), ternary fine aggregate (sand, RFA and fine cupola furnace slag (FCFS)), and ternary coarse aggregate (granite, RCA, and coarse cupola furnace slag (CCFS). A mix ratio of 1:2:4 by weight of cement, fine aggregate, and coarse aggregate with water to cement ratio $(\mathrm{w} / \mathrm{c})$ of 0.55 was adopted. The cement was replaced in the percentage of $0,5,10,15,20$, and 25 while the aggregates were replaced in $0,10,20,30,40$, and 50 percent. In the first mix, OPC was partially replaced with GCFS in the concrete, forming a binary cement while the aggregates were kept constant. In the second and third mixes, sand and granite were partially replaced with FCFS and CCFS in the concrete (i.e., binary fine and coarse aggregate). In contrast, in the fourth mix, sand was completely replaced with FCFS and subsequently partially replaced with RFA. Finally, in the fifth mix, granite was completely replaced with CCFS and subsequently, partially replaced with RCA.

The aggregates were added dry so as not to modify the mix ratio and study performance. Additionally, a reference sample was made with $100 \%$ of natural aggregates and cement. The mixed quantity was calculated by the weighted method in accordance with BS 812: Part 104 (1985). The sand sample that was used as fine aggregate in the concrete was washed and oven-dried for 24 hours before further tests such as particle size distribution, specific gravity, etc. were carried out on it. In order to obtain continuously graded sand, the fine recycled aggregate and natural fine aggregate were allowed to pass through sieves of different sizes to guarantee a maximum particle size lesser than $4.75 \mathrm{~mm}$. The grading was done in conformity with BS 812: part 103 (1985) and the percentage passing through each set of sieves was determined. The oxide of the cement and GCFS was 
determined using the X-ray fluoresce analysis. Aggregate impact test (AIT) and aggregate crushing value (ACV) were also performed in accordance with the recommendation given in BS 812-112, 1990 and BS 812-110, 1990 respectively on the coarse aggregates to check their suitability.

The fresh concrete was also tested in accordance with British Standards (1881: Part 102 (1983) for slump which was used as the basis for comparison of the workability for the five mixes. The prepared fresh concrete was then poured into a standard concrete cube mould of $150 \times 150 \times 150 \mathrm{~mm}$ in three layers. Each layer was given 25 blows using a tamping rod as recommended by BS1881: Part 111 (1983). After 24 hours, the concrete was demoulded from the moulds and cured in the curing tank for 7, 14, 28, and 56 days. At each hydration time of $7,14,28$, and 56 days, three specimens of the concrete cube were removed from the curing tank, weighed, tested, and recorded for compressive strength. The durability of the optimum hardened concrete from the various mixes was studied using a scanning electron microscope (SEM) and the result was interpreted using the image analyzing software (imagej) to calculate the porosity of the concrete cubes. The mix design was carried out in accordance with the ACI method, and the proportion of mix is given in Table III-V.

\section{RESULTS AND DISCUSSIONS}

\section{A. Physical Properties of Aggregates and Cement}

The physical and chemical composition of cement, cupola slag, and other aggregates (recycled sandcrete and concrete) used are presented in Table I and II with their quantities presented in Table III-IV below. From the Table, the specific gravity value of OPC used is seen to be lower than that of the GGFS. For the fine aggregates used, FCFS has the highest value of specific gravity followed by RFA, while natural sand has the lowest value. Also, the water absorption value for RCA is seen to be the highest, this could be as a result of adhered mortar on the aggregate, then followed by CCFS and NCA. According to BS 812-110 and BS 812-112, the ACV and AIV for good aggregates should be less than $45 \%$, hence the aggregates are good for construction. The high values of ACV and AIV for RCA suggests the possibility of reduction in the compressive strength because recycled concrete exhibit a lower capacity to resist load and the possibility of increment in the compressive strength of cupola-granite aggregate.

The graphical presentation of the sieve analysis test conducted on both fine and coarse aggregates is presented in Fig. 1 and Fig. 2, respectively. The computed coefficient of uniformity $\left(\mathrm{C}_{\mathrm{u}}\right)$ and the coefficient of curvature $\left(\mathrm{C}_{\mathrm{c}}\right)$ of the aggregates are also presented in Table I. For well-graded sand, $\mathrm{C}_{\mathrm{c}}$ must be greater than 1 but less than 3 while $\mathrm{C}_{\mathrm{u}}$ must be greater than or equal to 6 , and for a well-graded granite, $\mathrm{C}_{\mathrm{c}}$ must be greater than 1 but less than 3 while $\mathrm{C}_{\mathrm{u}}$ must be greater than 4 . From the computed values, only the NFA and NCA are well graded while the rest are poorly graded. Table 2 compares the composition of the granulated cupola slag to that of a typical Portland cement. The test was carried out using X-ray Florescence Spectroscopy (XRF). It was observed that the sum of the percentage composition of the oxides in the cupola slag is $73.99 \%\left(\mathrm{SiO}_{2}+\mathrm{Al}_{2} \mathrm{O}_{3}+\mathrm{Fe}_{2} \mathrm{O}_{3}\right)$ and according to [20], a pozzolan should have at least $70 \%$ for the sum of those oxides.

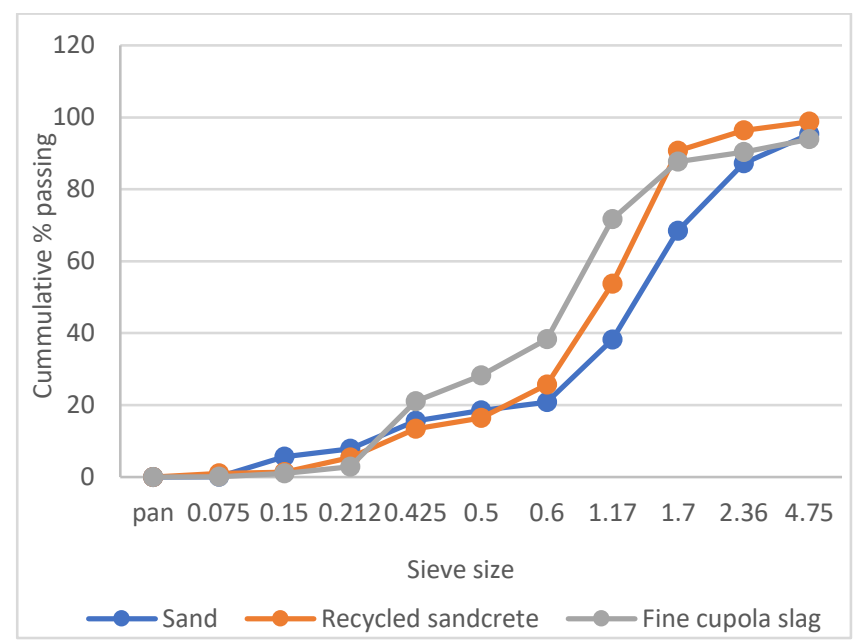

Fig. 1. Particle size distribution curve for fine aggregate.

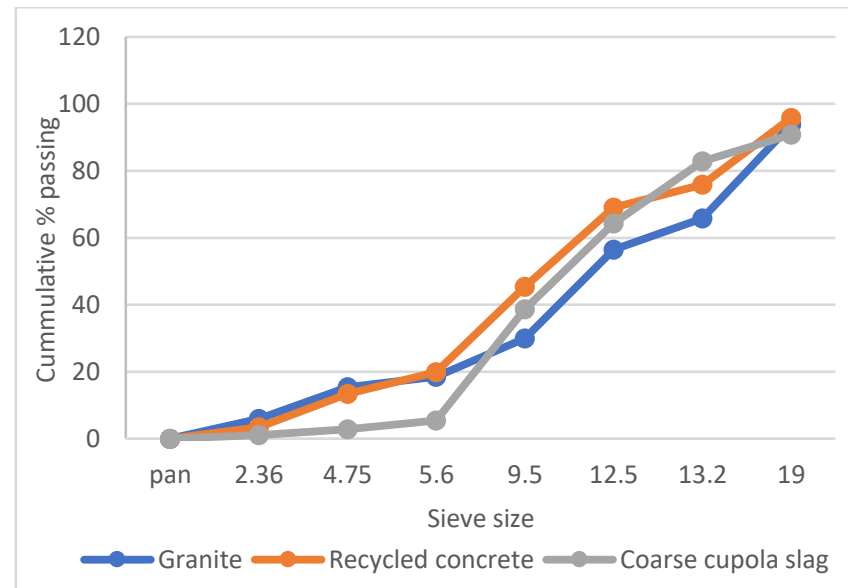

Fig. 2. Particle size distribution curve for coarse aggregates.

TABLE I: THE RESUlT OF THE MINERAL COMPOSITION OF GRANULATED CuPOla SLAG AND ORdinARY CEMENT USED FOR THE TEST USING X-RAY

\begin{tabular}{cccc}
\hline Common Name & Oxide & $\begin{array}{c}\text { Portland } \\
\text { cement Content } \\
(\%)\end{array}$ & $\begin{array}{c}\text { Granulated Cupola } \\
\text { Slag }(\%)\end{array}$ \\
\hline Iron & $\mathrm{Fe}_{2} \mathrm{O}_{3}$ & 3.28 & 20.76 \\
Sulfuric anhydride & $\mathrm{SO}_{3}$ & 2.04 & 8.06 \\
Alumina & $\mathrm{Al}_{2} \mathrm{O}_{3}$ & 5.78 & 10.40 \\
Lime & $\mathrm{CaO}$ & 61.52 & 10.54 \\
Magnesia & $\mathrm{MgO}$ & 2.08 & 0.22 \\
Alkalis & $\mathrm{Na}_{2} \mathrm{O}$ & 0.78 & 0.32 \\
Silica & $\mathrm{SiO}_{2}$ & 21.02 & 42.83 \\
\hline
\end{tabular}

\section{B. Concrete Workability}

Fig. 3 and 4 show the slump values for the various mixes. It was observed that the slump value decreases as the percentage replacement of cement, sand, and granite with GCFS, FCFS, CCFS. RFA and RCA increases. This is an indication that the inclusion of cupola slag in the mix has an effect on the cohesiveness of the various mixes. The decrease in slump value can be attributed to the carbon content in cupola slag and adhered mortar on recycled construction aggregates which tends to increase their affinity for water. The slump value for the control concrete is $68 \mathrm{~mm}$ while that of cement replacement with granulated cupola ranged from $66 \mathrm{~mm}$ to $64 \mathrm{~mm}$. For the natural aggregates (sand and 
granite) replacement, it ranges from $67 \mathrm{~mm}$ to $55 \mathrm{~mm}$. It can

be said that all the mixes exhibit a medium slump.

TABLE II: PhysicAl PROPERTIES OF AGgREgATES AND CEMENT

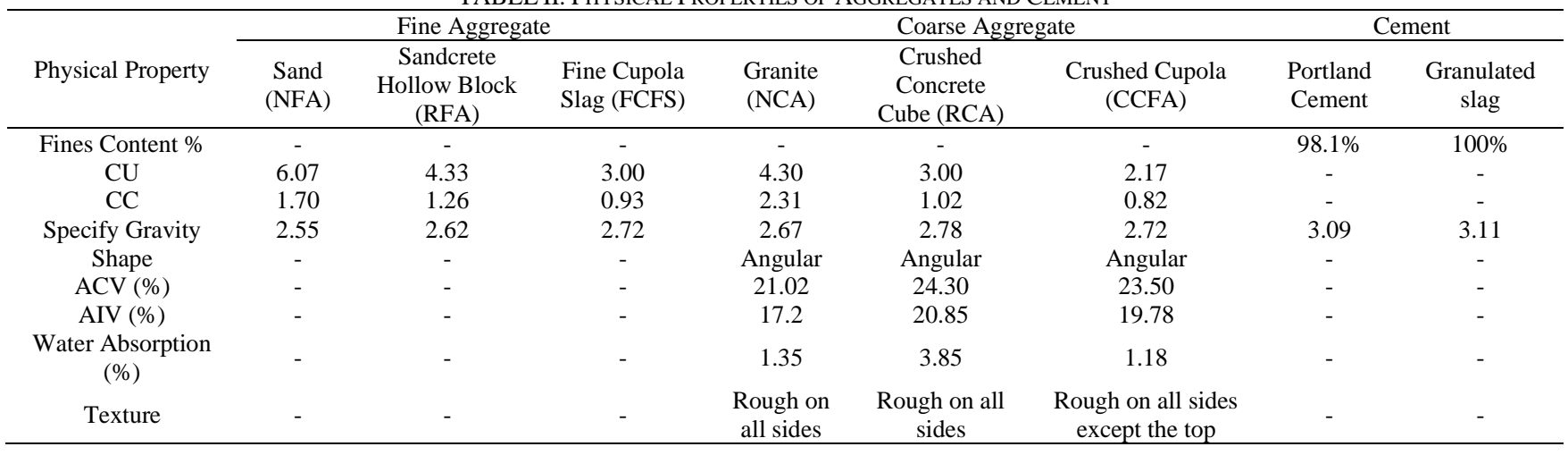

TABLE III: MiX DESIGN COMPOSITION FOR PARTIAL REPLACEMENT OF CEMENT WITH GRANULATED CUPOLA SLAG

\begin{tabular}{ccccc}
\hline \% Replacement & OPC $\left(\mathrm{kg} / \mathrm{m}^{3}\right)$ & $\begin{array}{c}\text { Granulated cupola } \\
\text { slag }\left(\mathrm{kg} / \mathrm{m}^{3}\right)\end{array}$ & Sand $\left(\mathrm{kg} / \mathrm{m}^{3}\right)$ & Granite $\left(\mathrm{kg} / \mathrm{m}^{3}\right)$ \\
\hline $0 \%$ & 300 & 0 & 689 & 1252 \\
$5 \%$ & 285 & 15 & 689 & 1252 \\
$10 \%$ & 270 & 30 & 689 & 1252 \\
$15 \%$ & 255 & 45 & 689 & 1252 \\
$20 \%$ & 240 & 60 & 689 & 1252 \\
$25 \%$ & 225 & 75 & 689 & 165 \\
\end{tabular}

TABLE IV: MiX DESIGN COMPOSITION FOR PARTIAL REPLACEMENT OF SAND AND GRANiTE WiTh FINE AND COARSE CUPOLA SLAG

\begin{tabular}{|c|c|c|c|c|c|c|}
\hline$\%$ Replacement & OPC $\left(\mathrm{kg} / \mathrm{m}^{3}\right)$ & Sand $\left(\mathrm{kg} / \mathrm{m}^{3}\right)$ & $\begin{array}{l}\text { Fine Cupola } \\
\text { Slag }\left(\mathrm{kg} / \mathrm{m}^{3}\right)\end{array}$ & Granite $\left(\mathrm{kg} / \mathrm{m}^{3}\right)$ & $\begin{array}{c}\text { Coarse Cupola } \\
\text { Slag }\left(\mathrm{kg} / \mathrm{m}^{3}\right)\end{array}$ & Water (lit.) \\
\hline $0 \%$ & 300 & 689 & 0 & 1252 & 0 & 165 \\
\hline $10 \%$ & 300 & 620.1 & 68.9 & 1126.8 & 125.2 & 165 \\
\hline $20 \%$ & 300 & 551.2 & 137.8 & 1001.6 & 250.4 & 165 \\
\hline $30 \%$ & 300 & 482.3 & 206.7 & 876.4 & 375.6 & 165 \\
\hline $40 \%$ & 300 & 413.4 & 275.6 & 751.2 & 500.8 & 165 \\
\hline $50 \%$ & 300 & 344.5 & 344.5 & 626 & 626 & 165 \\
\hline
\end{tabular}

TABLE V: Mix DESIGN COMPOSITION FOR COMPLETE REPLACEMENT OF SAND AND GRANITE WITH CUPOLA AND CONSTRUCTION AGGREGATES

\begin{tabular}{|c|c|c|c|c|c|c|c|c|c|}
\hline $\begin{array}{l}\% \text { of } \\
\text { cupola }\end{array}$ & $\begin{array}{c}\% \text { of } \\
\text { construction } \\
\text { aggregates }\end{array}$ & $\mathrm{OPC}\left(\mathrm{kg} / \mathrm{m}^{3}\right)$ & $\begin{array}{c}\text { Sand } \\
\left(\mathrm{kg} / \mathrm{m}^{3}\right)\end{array}$ & $\begin{array}{l}\text { Fine Cupola } \\
\text { Slag }\left(\mathrm{kg} / \mathrm{m}^{3}\right)\end{array}$ & $\begin{array}{c}\text { Recycled } \\
\text { sandcrete } \\
\left(\mathrm{kg} / \mathrm{m}^{3}\right)\end{array}$ & $\begin{array}{l}\text { Granite } \\
\left(\mathrm{kg} / \mathrm{m}^{3}\right)\end{array}$ & $\begin{array}{c}\text { Coarse } \\
\text { Cupola Slag } \\
\left(\mathrm{kg} / \mathrm{m}^{3}\right)\end{array}$ & $\begin{array}{c}\text { Recycled } \\
\text { concrete } \\
\left(\mathrm{kg} / \mathrm{m}^{3}\right) \\
\end{array}$ & $\begin{array}{l}\text { Water } \\
\text { (lit.) }\end{array}$ \\
\hline $0 \%$ & $0 \%$ & 300 & 689 & 0 & 0 & 1252 & 0 & 0 & 165 \\
\hline $100 \%$ & $0 \%$ & 300 & 0 & 689 & 0 & 0 & 1252 & 0 & 165 \\
\hline $90 \%$ & $10 \%$ & 300 & 0 & 620.1 & 68.9 & 0 & 1126.8 & 125.2 & 165 \\
\hline $80 \%$ & $20 \%$ & 300 & 0 & 551.2 & 137.8 & 0 & 1001.6 & 250.4 & 165 \\
\hline $70 \%$ & $30 \%$ & 300 & 0 & 482.3 & 206.7 & 0 & 876.4 & 375.6 & 165 \\
\hline $60 \%$ & $40 \%$ & 300 & 0 & 413.4 & 275.6 & 0 & 751.2 & 500.8 & 165 \\
\hline $40 \%$ & $50 \%$ & 300 & 0 & 344.5 & 344.5 & 0 & 626 & 626 & 165 \\
\hline
\end{tabular}

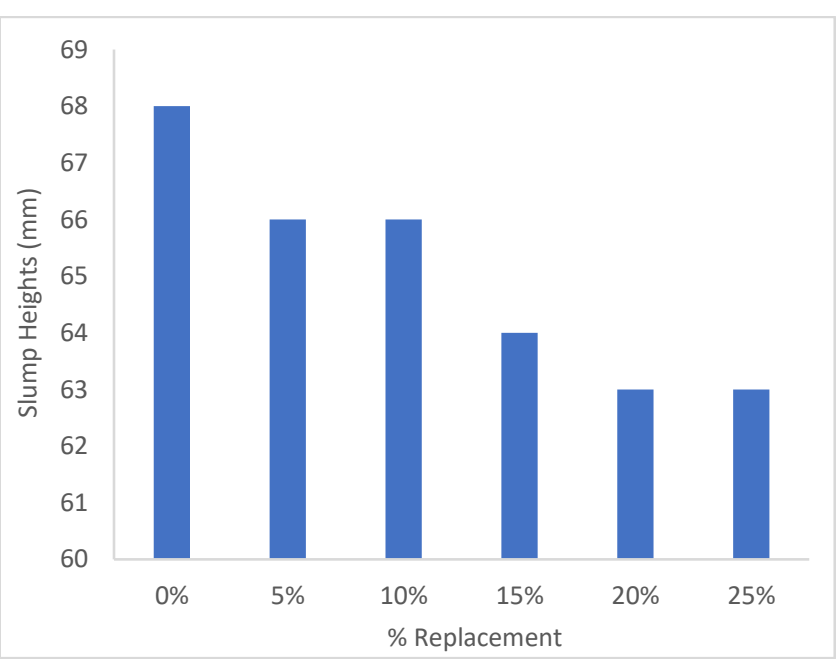

Fig. 3. Slump values for cement replacement with cupola.

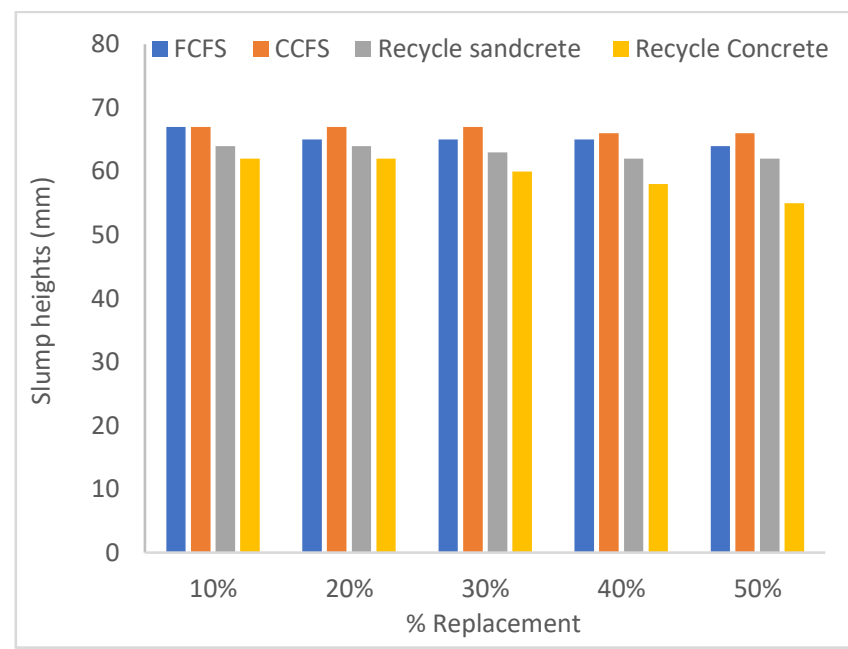

Fig. 4. Slump values for aggregates replacement with coarse cupola, recycled concrete, and recycled sandcrete. 


\section{Compressive Strength \\ 1) Cupola as substitute replacement for cement and aggregates}

The results of the compressive strengths of concrete from various mixes of cement, sand, and granite replacement with cupola slag at 7, 14, 28, and 56 days are presented in Fig, 5 to Fig, 7 while the results for the complete replacement of sand and granite is shown in Fig, 8 and Fig 9. It was noticed that the concrete strength for all the mixes increases with an increase in curing days. The values at $0 \%$ which is the control have a compressive strength of $15.74 \mathrm{~N} / \mathrm{mm}^{2}$ and $17.66 \mathrm{~N} / \mathrm{mm}^{2}$ at 28 and 56 days, respectively. At $5 \%$ and $10 \%$ replacement, an increase of $13.22 \%, 10.53 \%$ and $29.42 \%, 25.43 \%$ was observed at 28 and 56 days, respectively when compared with the control. However, at $15 \%, 20 \%$, and $25 \%$ replacement, there was a decrease of $14.99 \%, 33.04 \%$, and $33.16 \%$ in strength at 28 days of curing. Similar trends were reported by [21] when GCFS was used as a partial replacement for cement. The variations in strengths can be said to be due to the changes in the oxide composition of the Portland-slag cement by adding the granulated cupola slag.

The compressive strength pattern was however different when cupola slag was used as fine and coarse aggregates. For fine aggregate, a progressive increase in strength was observed from $10 \%$ to $20 \%$ replacement but a steady decrease started occurring at 30\% till 50\%. Although at 30\% replacement, there was still an increase of $21.10 \%$ and $12.29 \%$ in strength at 28 and 56 days when compared with the control. The highest compressive strength $22.8 \mathrm{~N} / \mathrm{mm}^{2}$ and $23.72 \%$ occurred at $20 \%$ replacement accounting for $54.75 \%$ and $12.29 \%$ in strength at 28 and 56 days. Conversely, at 28 days a decrease of $5.50 \%$ and $27.54 \%$ was witnessed at $40 \%$ and $50 \%$. For the partial replacement of granite with CCFS, the values of the compressive strength at $10 \%$ happens to be the highest which are almost approximately the same as the control sample at 28 and 56 days. Subsequent replacement at 20\%, 30\%, 40\%, and 50\% led to a decrease in strength with the least occurring at $50 \%$.

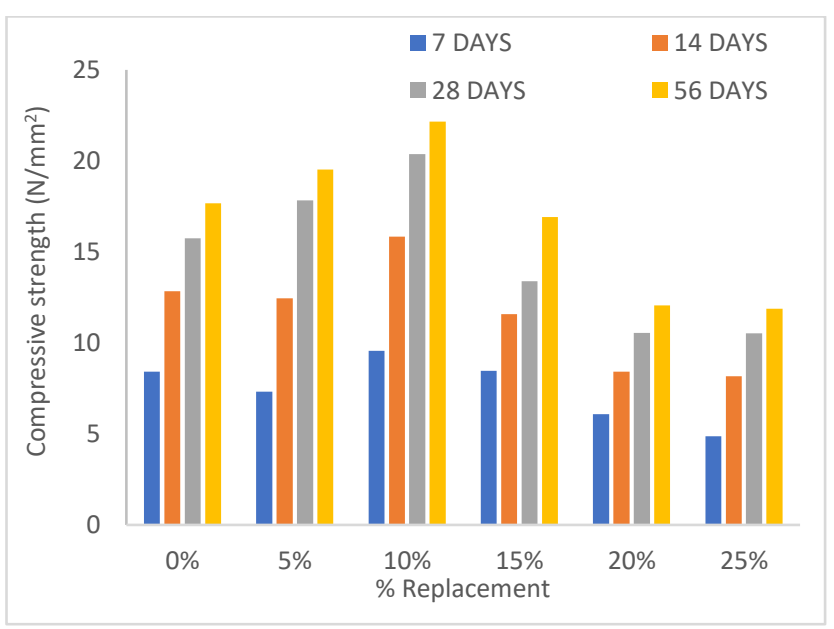

Fig. 5. Variation of compressive strength with slag-cement content.

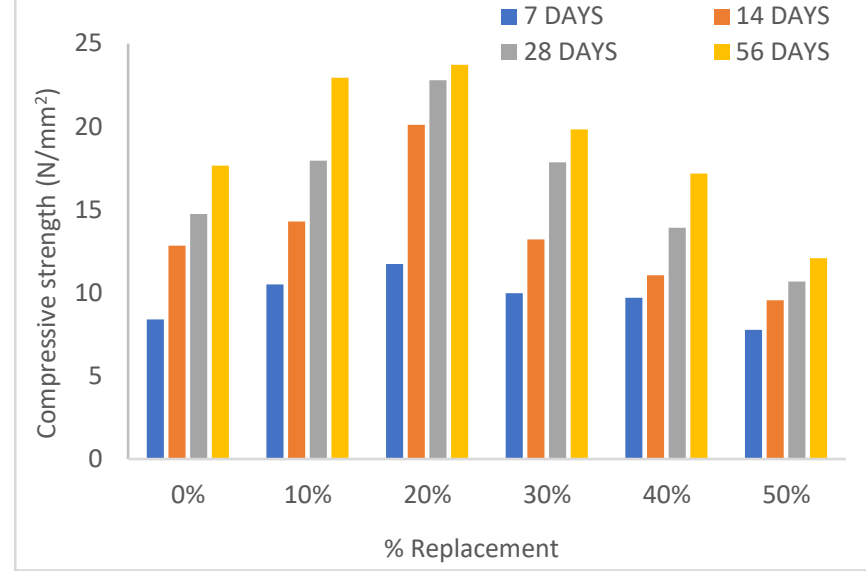

Fig. 6. Variation of compressive strength with slag-sand content.

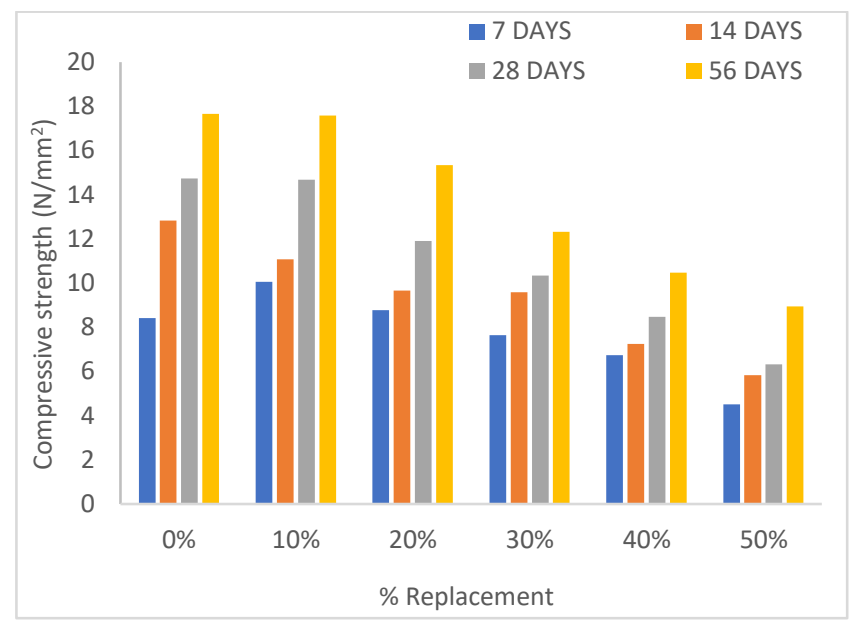

Fig. 7. Variation of compressive strength with slag-granite content.

2) Complete replacement of natural aggregates with cupola slag and recycled construction aggregates

The results obtained from the compressive strength test when sand and granite were completely replaced with cupola slag and subsequently partially replaced with crushed sandcrete and concrete are presented in Fig. 8 and Fig. 9. It can be seen from the result in Fig 8 that the strength of concrete produced from the complete replacement (100\%) of sand with fine cupola was higher than the strength produced when the cupola was replaced at different percentages with recycled sandcrete. Also, a gradual decrease in strength was noticed as the percentage of recycled sandcrete in the concrete increased. A decrease of $6.31 \%$ and $6.29 \%$ at 28 and 56 days was incurred when sand was completely replaced with FCFS. Subsequent replacement of cupola slag with recycled sandcrete at 10\%, 20\%,30\%, $40 \%$ and $50 \%$ led to further decrease of $7.46 \%, 9.57 \%, 14.04 \%, 34.87 \%$ and $55.09 \%$ in strength.

For the complete replacement of granite with CCFS (100\% replacement), there was a decrease of $30.33 \%$ in strength at 28 days. However, at $10 \%$ and $20 \%$ replacement of CCFS with RCA, an improvement in strength was noticed $10.85 \mathrm{~N} / \mathrm{mm}^{2}$ and $10.32 \mathrm{~N} / \mathrm{mm}^{2}$ although lower in strength when compared with $14.74 \mathrm{~N} / \mathrm{mm}^{2}$ produced for the control sample. Further replacement at 30\%, $40 \%$ and $50 \%$ gave a much lesser strength $9.64 \mathrm{~N} / \mathrm{mm}^{2}, \quad 8.89 \mathrm{~N} / \mathrm{mm}^{2}$ and $8.14 \mathrm{~N} / \mathrm{mm}^{2}$ as against $10.27 \mathrm{~N} / \mathrm{mm}^{2}$ for $100 \%$ replacement at 28 days. 


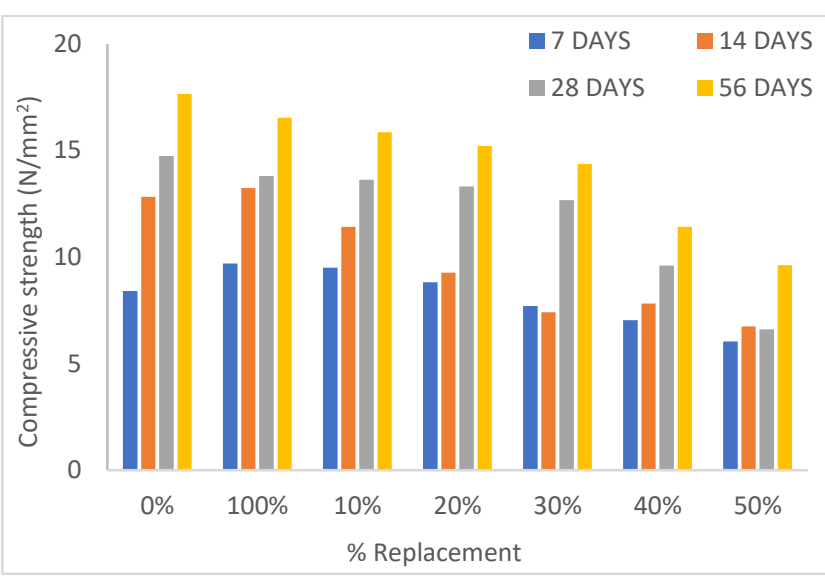

Fig. 8. Variation of compressive strength with complete replacement of sand on the concrete.

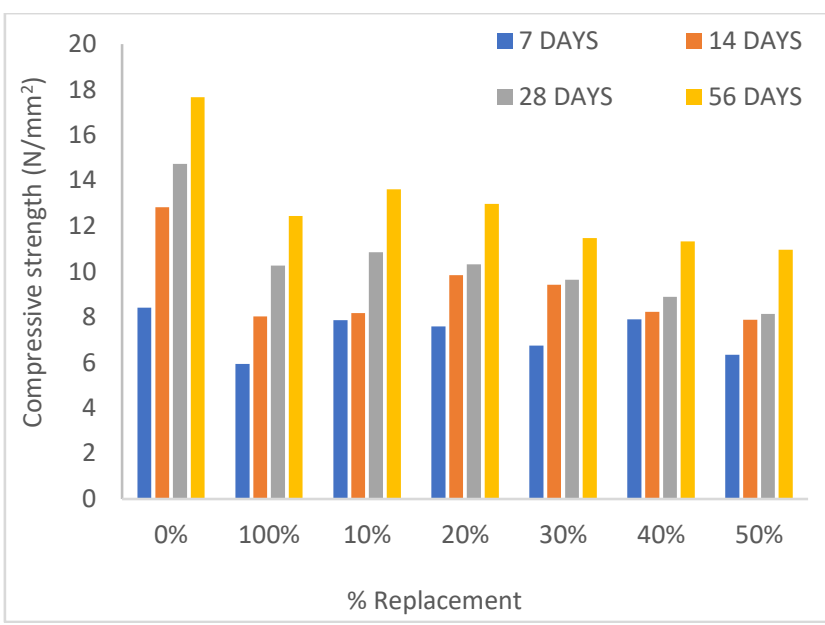

Fig. 9. Variation of compressive strength with complete replacement of granite.

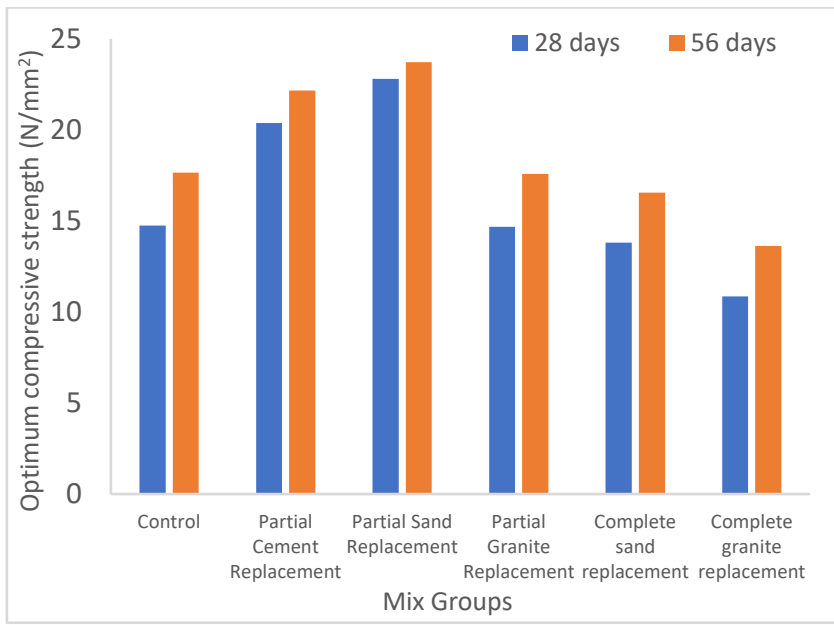

Fig. 10. Variation in optimum compressive strength from each mix.

\section{3) Optimum strength from each replacement}

Fig. 10 depicts the result of optimum compressive strength from each of the mixes at 28 and 56 days. The partial replacement of cement and sand with GCFS and FCFS produces a compressive strength that is higher $20.37 \mathrm{~N} / \mathrm{mm} 2$, $22.15 \mathrm{~N} / \mathrm{mm}^{2}$, and $22.81 \mathrm{~N} / \mathrm{mm}^{2}, 23.72 \mathrm{~N} / \mathrm{mm}^{2}$ which are much higher than the control $14.74 \mathrm{~N} / \mathrm{mm}^{2}$ and $17.66 \mathrm{~N} / \mathrm{mm}^{2}$ at 28 and 56 days, respectively. At $10 \%$ replacement of granite with CCFS, the compressive strength is relatively close to that of the control with just $0.41 \%$ and $0.45 \%$ difference in strength at 28 and 56 days. However, the complete replacement of traditional aggregates with cupolasandcrete and cupola-concrete produces a lesser strength.

\section{Microstructure Analysis}

The microstructure and surface morphology of the hydrated concrete produced from the percentage replacement that gave the highest compressive strength from each mix after being cured for 56 days was studied using a scanning electron microscope (SEM) of 500x enlargement and image analyzer (Imagej software). Fig. 11a to 11f shows the SEM result, while Fig. 11a' to 11f' shows the output from the image analysis of the SEM result. The purple area on the SEM image is used to calculate the percentage area of the surface porosity on the concrete.

The SEM result and the image analysis of the control can be seen in Fig. 11a and 11a', respectively, the percentage area of the pore is calculated to be $8.8 \%$. From Fig. 11 b, the SEM result of the concrete produced when $10 \%$ of cement is replaced with GCFS is shown, some gel-like substances are seen to appear, known to be C-S-H gel, the main influencer on the development of concrete strength. When slag is added to cement, its silicate reacts with $\mathrm{C}-\mathrm{H}$ formed in ordinary Portland cement hydration, forming additional C-S-H gel which reduces the porosity of the concrete produced, resulting in a harder cementitious paste with increased strength, thus conforming to the results from the compressive strength. Fig. 15b' shows the percentage area of the concrete pores to be $7.95 \%$. Fig. $11 \mathrm{c}$ and $15 \mathrm{c}$ ' shows the result of the SEM and image analysis when $20 \%$ of natural sand is replaced with FCFS, the percentage area of pores for this specimen is given to be $4.97 \%$ which is the lowest for all the specimens. The incorporation of cupola slag as either cement or fine aggregate replacement appears to lessen the porosity, as such, giving more strength to the concrete. The decrease in porosity was reported by [21] to be a result of the fineness nature of the cupola slag which fills more void areas in the concrete. However, Fig. 11d and 11d' produces a higher porosity of $8.8 \%$ when $10 \%$ of CCFS is used to partially replace granite. This increase in porosity can be attributed to the size of the coarse cupola and its angular shape.

Several studies [22], [23] and [24] have shown that recycled construction aggregates show higher porosity than natural aggregates and the result from Fig. 15e and 15e' also confirms this. Fig. 15e is the SEM result from specimen produced when natural sand is completely replaced with $90 \%$ of the fine cupola and $10 \%$ recycled sandcrete while Fig. $15 f$ also shows the complete replacement of granite with $90 \%$ of the coarse cupola and $10 \%$ of recycled concrete, both give a higher percentage area of pores of $9.96 \%$ and $26.32 \%$ respectively. Since concrete permeability increases with an increase in porosity, to achieve high durability, concrete porosity should be kept low to reduce its permeability. A very high impermeable concrete will reduce or eliminate the ingress of water and other aggressive chemicals and gases. 


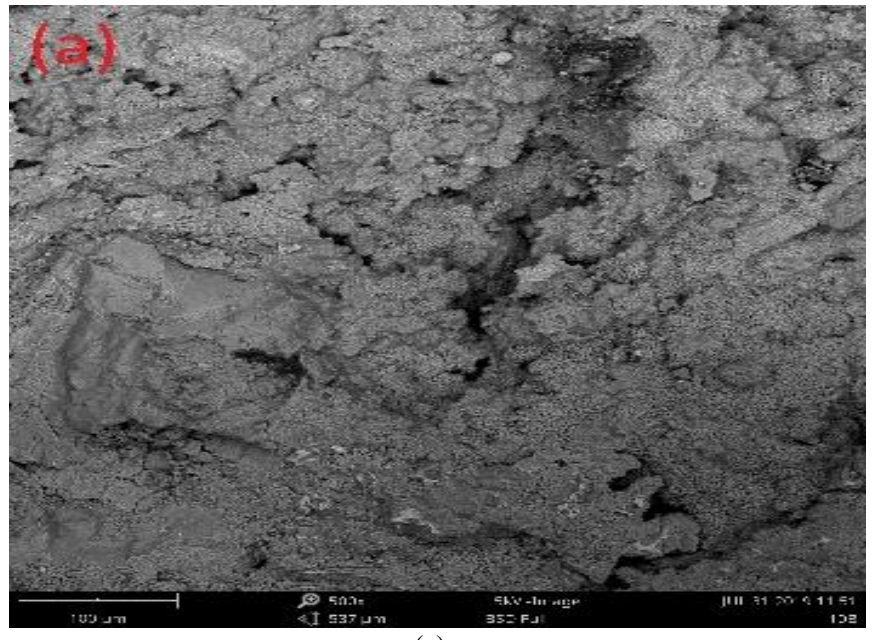

(a)

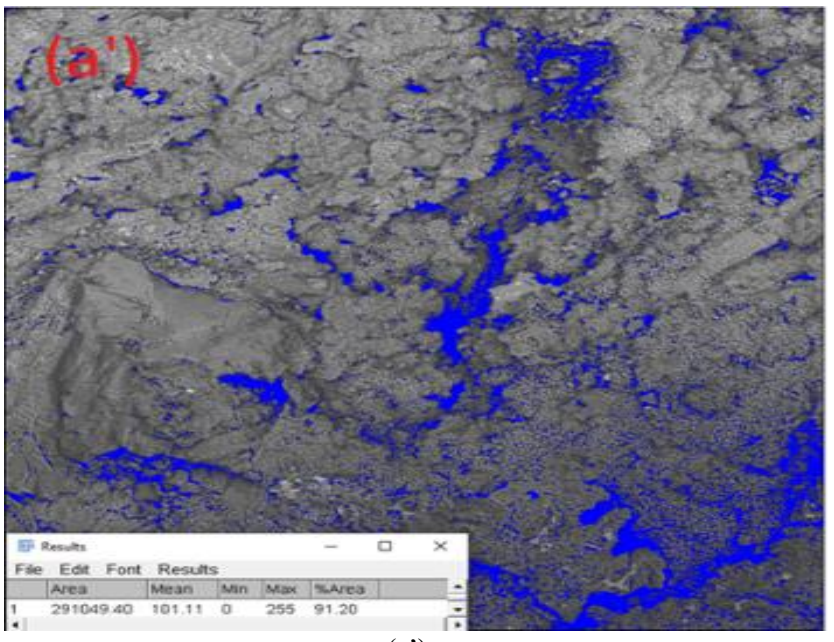

(a')

Fig. 11. (a) Microstructure of the control concrete at 500X (a') Surface porosity of the control concrete using image.

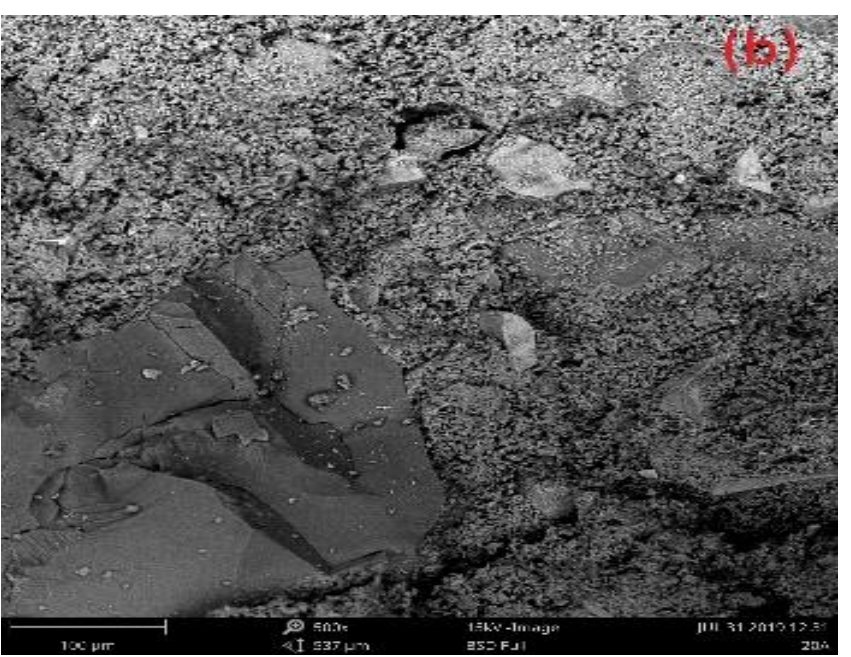

(b)

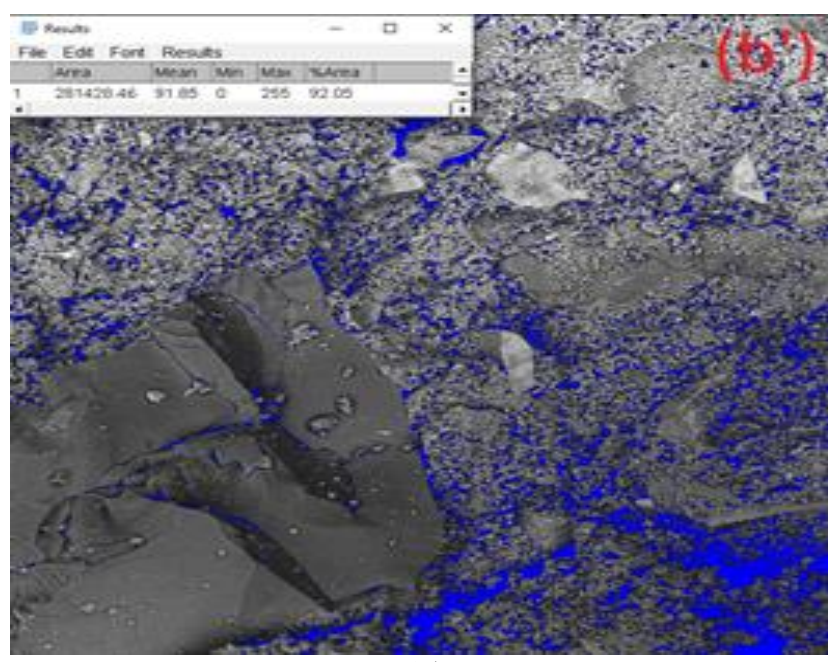

(b')

Fig. 11. (b) Microstructure view of the concrete produced from $10 \%$ replacement of cement with granulated cupola furnace slag at 500X (b') Surface porosity on the SEM image using image.

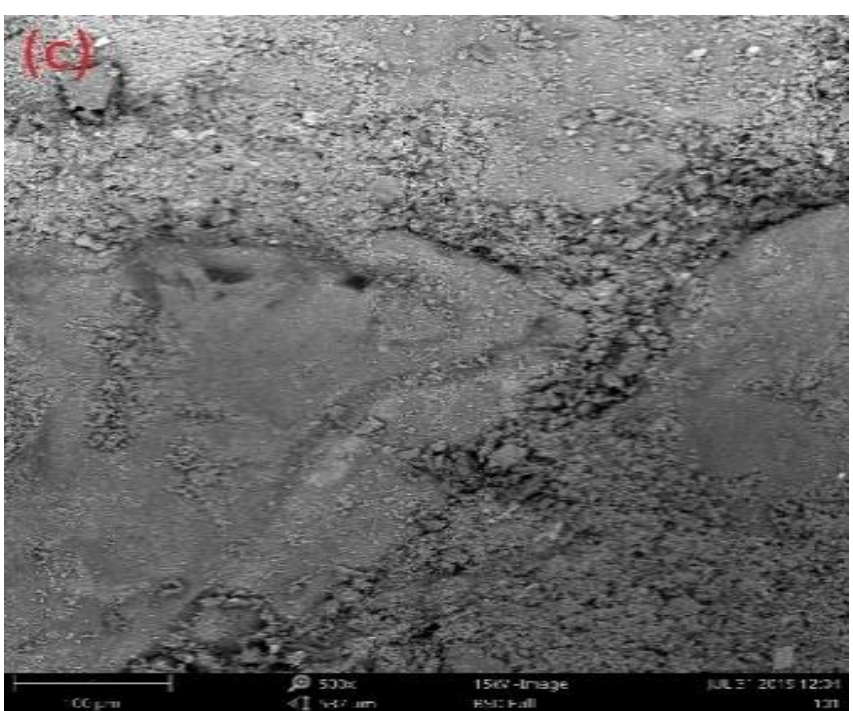

(c)

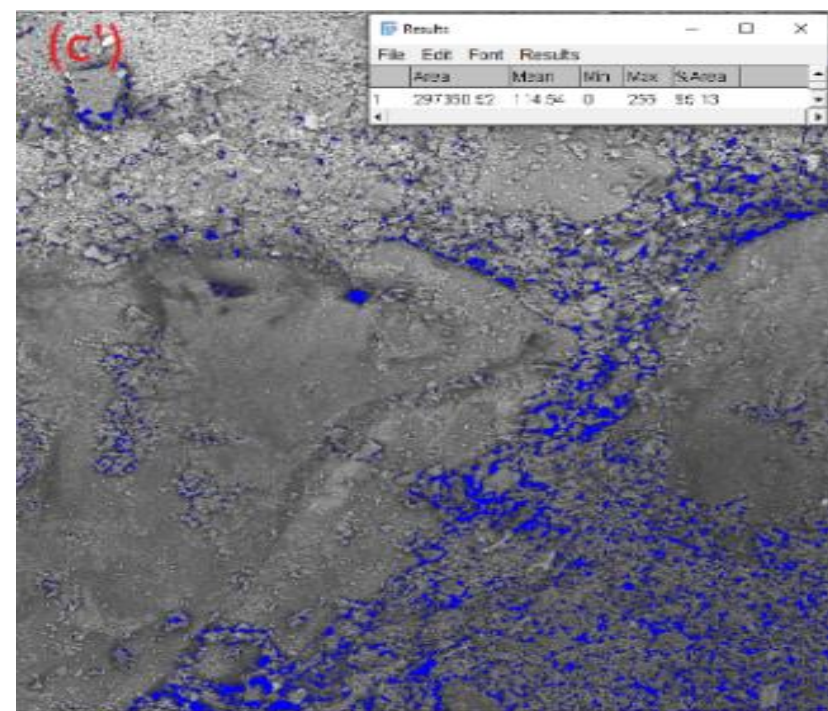

(c')

Fig. 11. (c) Microstructure view of the concrete produced from $20 \%$ replacement of sand with fine cupola furnace slag at $500 \mathrm{X}$ (c') Surface porosity of the SEM image using image. 

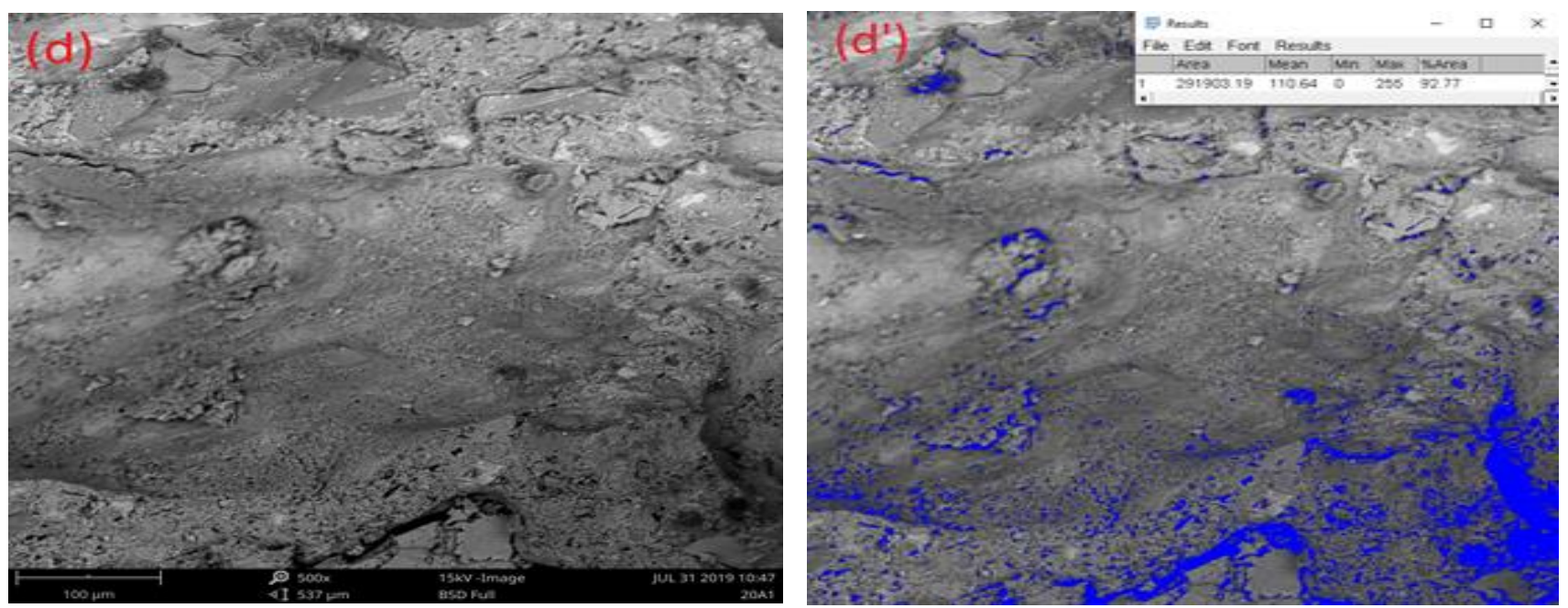

(d)

(d')

Fig. 11. (d) Microstructure view of the concrete produced from 10\% replacement of granite with coarse cupola furnace slag at 500X (d') Surface porosity of the SEM image using image.

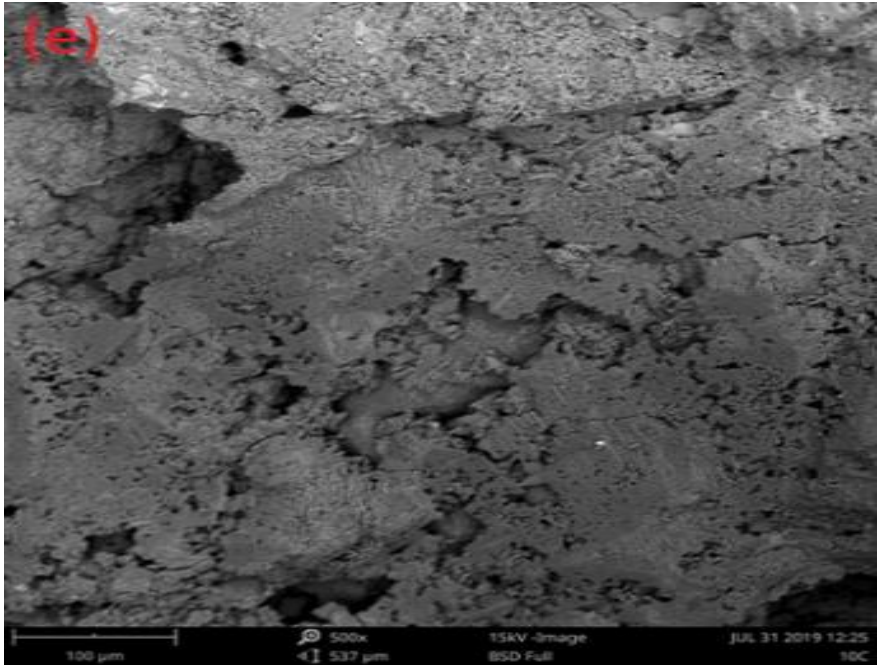

(e)

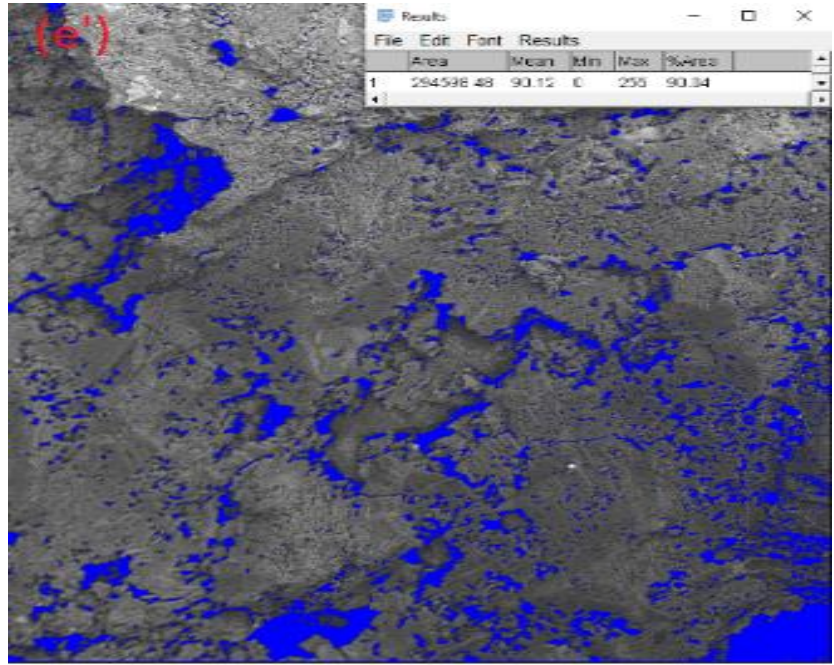

(e')

Fig. 11. (e) Microstructure view of the concrete produced from the complete replacement of sand with $10 \%$ of recycled sandcrete and $90 \%$ of fine Cupola furnace slag at 500X (e') Surface porosity of the SEM image using image.

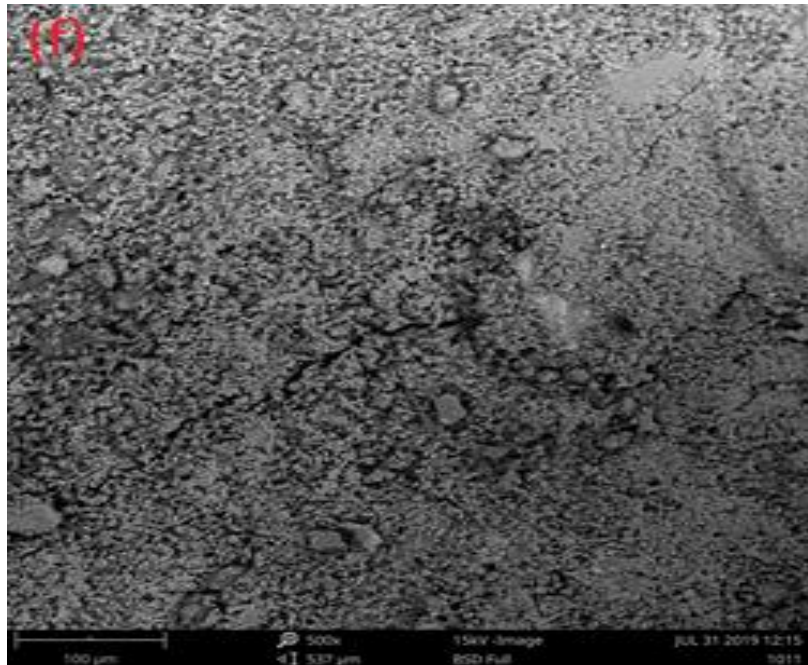

(f)

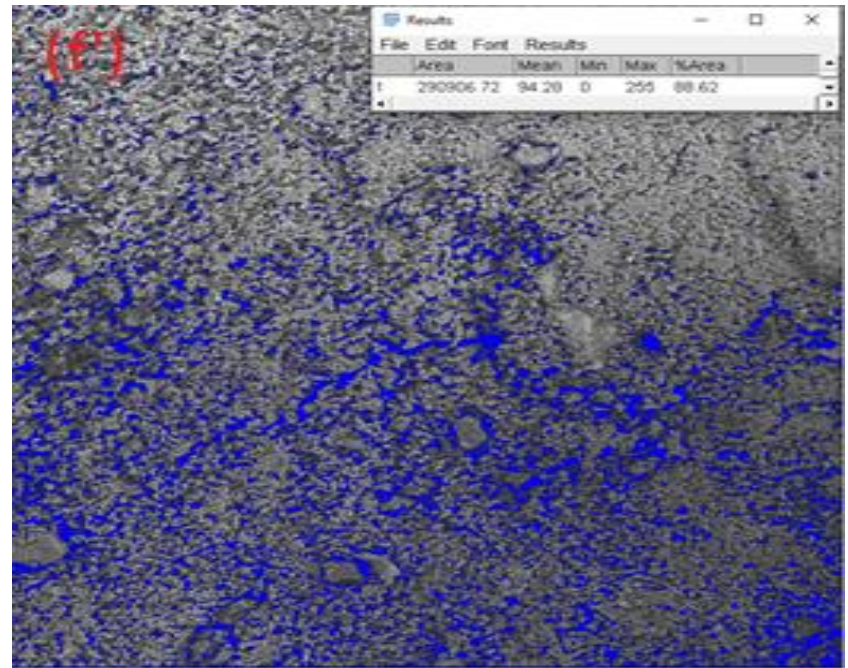

(f')

Fig. 11. (f) Microstructure view of the concrete produced from the complete replacement of granite with $10 \%$ of recycled concrete and $90 \%$ of coarse cupola furnace slag at 500X (f') Surface porosity of the SEM image using image. 


\section{CONCLUSION}

In this research, the influence of cupola furnace slag and recycled construction aggregates as replacements of cement and natural aggregates has been studied. The incorporation of these materials in concrete gives a varying influence on the properties of concrete depending on the percentage of replacement. A replacement of up to $10 \%$ of GCFS for cement leads to an increase in compressive strength. A similar increment was observed when fine aggregate was replaced with up to $30 \%$ of FCFS, while a downward trend in compressive strength was recorded for all percentage replacement of CCFS for coarse aggregates. Other conclusions drawn from the test results include:

1. The workability of concrete decreases as the percentage of cupola slag and recycled construction aggregates increases in all mixes.

2. At $5 \%$ and $10 \%$ replacement of cement with GCFS, a high compressive strength compared to the control was obtained. Other percentage replacement at 15, 20, and 25\% resulted in a low compressive strength.

3. At $10 \%, 20 \%$, and $30 \%$ replacement of sand with FCFS, the values of the compressive strength gotten were higher than the control.

4. The partial replacement of granite with CCFS gave a value lesser than the control in the mixes but at $10 \%$ and $20 \%$ replacement, the compressive strength was higher than 15 $\mathrm{N} / \mathrm{mm} 2$ recommended for $1: 2: 4 \mathrm{mix}$.

5 . The complete replacement of sand and granite with cupola furnace slag and recycled construction aggregates gave a lesser compressive strength.

6. The introduction of cupola furnace slag as partial replacement of cement and sand decreases the porosity of the concrete as shown in the SEM images, the material modifies the pores in the concrete microstructure through filler effect and the production of more $\mathrm{C}-\mathrm{S}-\mathrm{H}$, which will help improve the durability of concrete.

\section{REFERENCES}

[1] A. M. Maidodo, M. Azizan, and A. A. Abdullahi. Urban Solid Waste Development: A Review of Nigeria's Waste Management Policy, International Journal of Engineering, Management, Applied Science and Technology, vol. 11, no. 5, pp. 97-108, 2020.

[2] N. Ikpeze. Safe Disposal of Municipal Wastes in Nigeria: Perspectives on a rights-based approach, Journal of Sustainable Development Law and Policy, Vol. 3, no. 1, pp. 72 - 86, 2014.

[3] A. Adeyemi, J. Olorunfemi, and T. Adewoye. Waste Scavenging in Third World Cities; A Case Study in Ilorin, Nigeria, Environmentalist, vol. 21 , no. 5, pp. 93 - 96, 2012.

[4] I. A. Hussein, S. M. Mona. Solid waste issue: Sources, composition, disposal, recycling, and valorization, Egyptian Journal of Petroleum, vol. 27 , no. 4, pp. 1275 - 1290, 2018.

[5] B. J. Meko, J. O. Ighalo. Utilization of waste papers ash as supplementary cementitious materials in $\mathrm{C} 25$ concrete: evaluation of fresh and hardened properties, Cogent Eng. Vol. 8, no. 1, 2021, DOI: $10.1080 / 23311916.2021 .1938366$.

[6] S. Maschio, G. Tonello, L. Piani, and E. Furlani. Fly and bottom ashes from biomass combustion as cement replacing components in mortars production: Rheological behavior of the pastes and materials compression strength, Chemosphere, vol. 85, no 4, pp. 666-671, 2011.

[7] M. Garcia, and J. Sousa-Coutinho. Strength and durability of cement with forest waste bottom ash, Construction and Building Materials, vol. 41, pp. 897-910, 2013.

[8] K. Ramakrishnan, G. Pugazhmani, R. Sripragadeesh, D. Muthu, C. Venkatasubramanian. Experimental study on the mechanical and durability properties of concrete with waste glass powder and ground granulated blast furnace slag as supplementary cementitious materials, Constr. Build. Mater. Vol. 156, pp. 739-749, 2017.

[9] O. A. Mohamed, and O. Najm. Effect of curing methods on compressive strength of sustainable self-consolidated concrete. IOP Conf. Ser. Mat. Sci. Eng. 2019. doi:10.1088/1757-899X/471/3/032059.

[10] S. Kenai and F. Debieb. The use of coarse and fine crushed bricks as aggregates in concrete, Construction and Building Material. Vol. 22, pp. $886-893,2008$.

[11] R. Kamala, and B. Krishna Rao. Reuse of Solid Waste from Building Demolition for the Replacement of Natural Aggregates, International Journal of Engineering and Advanced Technology. 2(1), pp. $74-76$, 2012.

[12] A. A. Aliabdo, A. E. Elmoaty, and M. M. Abdelbaset. Utilization of waste rubber in non-structural applications, Constr. Build. Mater. Vol. 91, pp. 195-207, 2015, doi: 10.1016/j.conbuildmat.2015.05.080.

[13] B. Zhang, and C. S. Poon. Sound insulation properties of rubberized lightweight aggregate concrete, J. Clean. Prod. 172, 3176-3185, 2018.

[14] Y. W. Choi, D. J. Moon, Y. J. Kim, M. Lachemi. Characteristics of mortar and concrete containing fine aggregate manufactured from recycled waste polyethylene terephthalate bottles, Construction and Building Materials. Vol. 23, pp. 2829-2835, 2009.

[15] S. Kou, C. S. Poon. Compressive strength pore size distribution and chloride-ion penetration of recycled aggregate concrete incorporating class-F fly ash. J. Wuhan Univ. Technol. Mater. Sci. Ed. Vol. 21, pp. 130-136, 2006.

[16] L. Ferreira, J. De Brito, N. Saikia. Influence of curing conditions on the mechanical performance of concrete containing recycled plastic aggregate, Constr. Build. Mater. Vol. 36, pp. 196-204, 2012.

[17] S. Yang, X. Yue, X. Liu, Y. Tong. Properties of self-compacting lightweight concrete containing recycled plastic particles, Construction and Building Materials. Vol. 84, pp. 444-453, 2015.

[18] A.M. Azhdarpour, M. R. Nikoudel, M. Taheri. The effect of using polyethylene terephthalate particles on physical and strength-related properties of concrete; a laboratory evaluation, Construction and Building Materials. Vol. 109, pp. 55-62, 2016.

[19] A. Domingo, C. Lázaro, F. L. Gayarre, C. Serrano, P. C. Lópeq-Colina Long-term deformation by creep and shrinkage in recycled aggregate concrete, Mater. Struct. Vol. 43, no. 8, pp. 1147-1160, 2010.

[20] ASTM International, Standard Specification for Fly Ash and Raw or Calcined Natural Pozzolan for Use as a Mineral Admixture in Portland Cement Concrete: ASTM International, 1994

[21] C. Arum, and O. G. Mark. Partial Replacement of Portland Cement by Granulated Cupola Slag - Sustainable Option for Concrete of Low Permeability, Civil and Environmental Research, vol. 6, no. 3, pp. 1726, 2014.

[22] M. G. José. Porosity of recycled concrete with substitution of recycled concrete aggregate - An experimental study, Cement and Concrete Research, vol. 32, no. 8, pp. 1301-1311, 2002. Doi: 10.1016/S00088846(02)00795-0.

[23] S. C. Kou, C. S. Poon. Properties of self-compacting concrete prepared with coarse and fine recycled concrete aggregates, Cement and concrete composite, vol. 31, no. 9, pp. 622-627, 2009

[24] T. Meng, H. Wei, X. Yang, B. Zhang, Y. Zhang, C. Zhang. Effect of mixed recycled aggregate on the mechanical strength and microstructure of concrete and different water-cement ratios, Materials, vol. 14, no. 10. 2631, 2021. https//doi.org/10.3390/ma14102631.

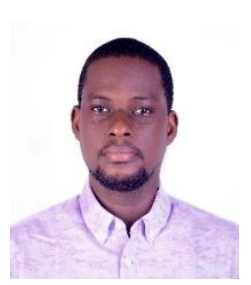

Adese Akorede John graduated with M.Eng honours in Civil Engineering with specialization in Structural Engineering from the Federal University of Technology Akure, Nigeria, and also bagged a B.Eng in Civil Engineering from the same school. He is a registered and practicing engineer who has worked on several construction projects.

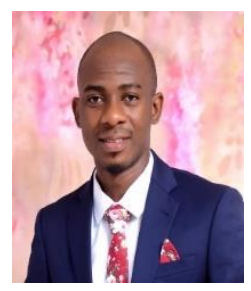

Olajide Olusola David is a Ph.D. candidate at the Department of Building, Civil and Environmental Engineering, Concordia University, Montreal, Canada. He had his bachelor's degree in civil engineering from the Federal University of Technology Akure (FUTA), Nigeria. Olusola's research is focused on the performance of concrete materials. He has been involved in projects assessing the influence of deterioration mechanisms like Alkali-Silica Reaction, Freezing and Thawing, and Corrosion on the performance of concrete. 
Olaoyenikan Olajide Alaba holds a B.Eng. and M.Eng. in Civil Engineering with specialization in Construction Engineering from the Federal University of Technology Akure, Nigeria. He is a practicing engineer with several years of experience in the built industry. He has also presented a journal on the use of waste materials as cement replacement in concrete at an engineering conference hosted by his alma mater in Nigeria. 